\title{
CORRIGENDUM
}

\section{Long noncoding RNA: noncoding and not coded}

Debra Toiber, Gabriel Leprivier and Barak Rotblat

Cell Death Discovery (2017) 3, 17035; doi:10.1038/cddiscovery.2017.35; published online 14 August 2017

Correction to: Cell Death Discovery (2017) 3, 16104; doi:10.1038/ cddiscovery.2016.104; published online 9 January 2017

Since the publication of this article, it has been noted that the affiliation for Gabriel Leprivier was incorrect. The correct affiliation is as follows:

${ }^{2}$ Clinic for Pediatric Oncology, Hematology and Clinical Immunology, Medical Faculty, Heinrich Heine University, Dusseldorf, Germany.

The authors apologise for any inconvenience caused by this error.
The original html and pdf versions of the paper have been rectified, and now carry the corrected paper.

(C) This work is licensed under a Creative Commons Attribution 4.0 article are included in the article's Creative Commons license, unless indicated otherwise in the credit line; if the material is not included under the Creative Commons license, users will need to obtain permission from the license holder to reproduce the material. To view a copy of this license, visit http://creativecommons.org/licenses/ by/4.0/

(c) The Author(s) 2017 